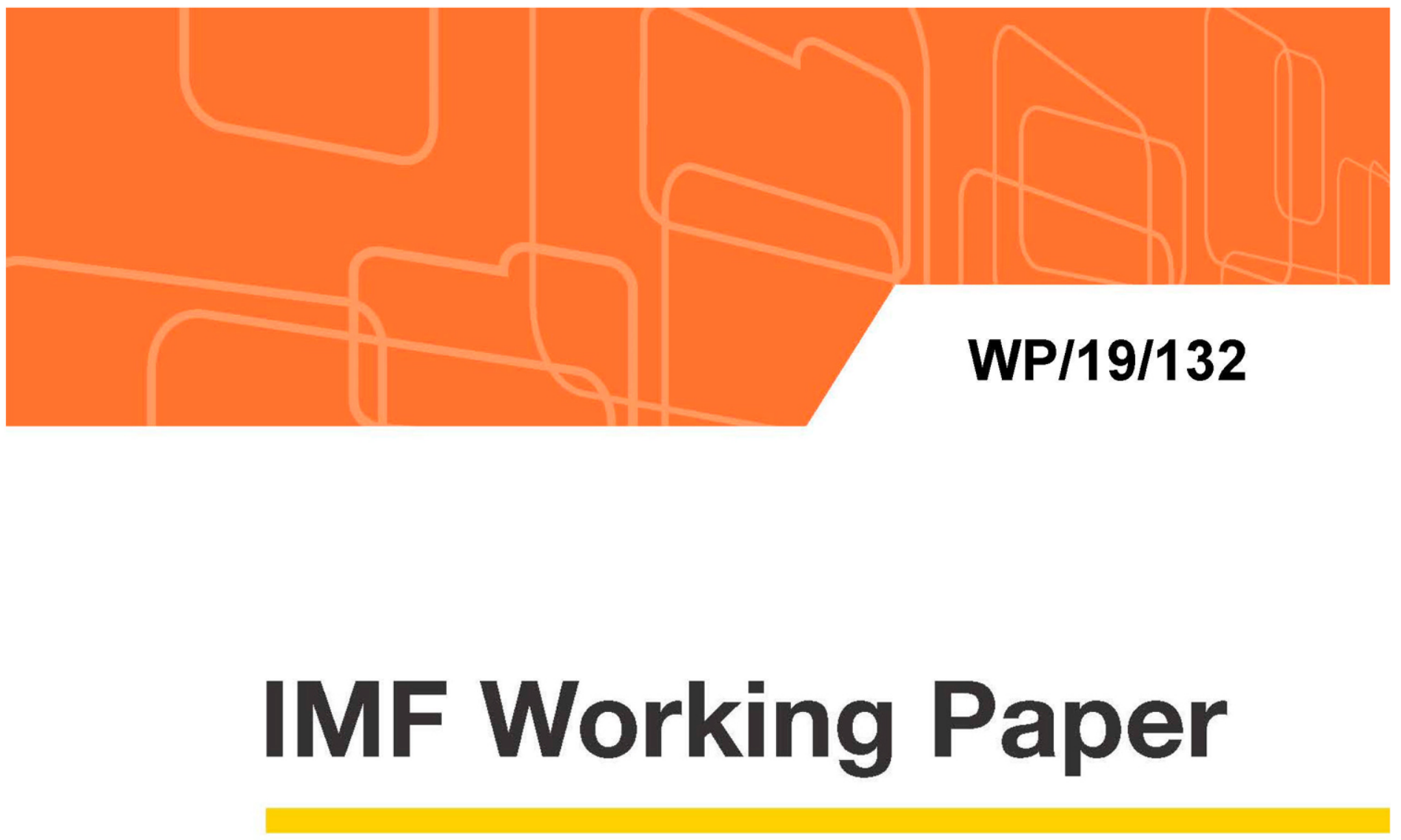

\title{
The Measurement of External Accounts
}

by Gustavo Adler, Daniel Garcia-Macia, and Signe Krogstrup

IMF Working Papers describe research in progress by the author(s) and are published to elicit comments and to encourage debate. The views expressed in IMF Working Papers are those of the author(s) and do not necessarily represent the views of the IMF, its Executive Board, or IMF management. 


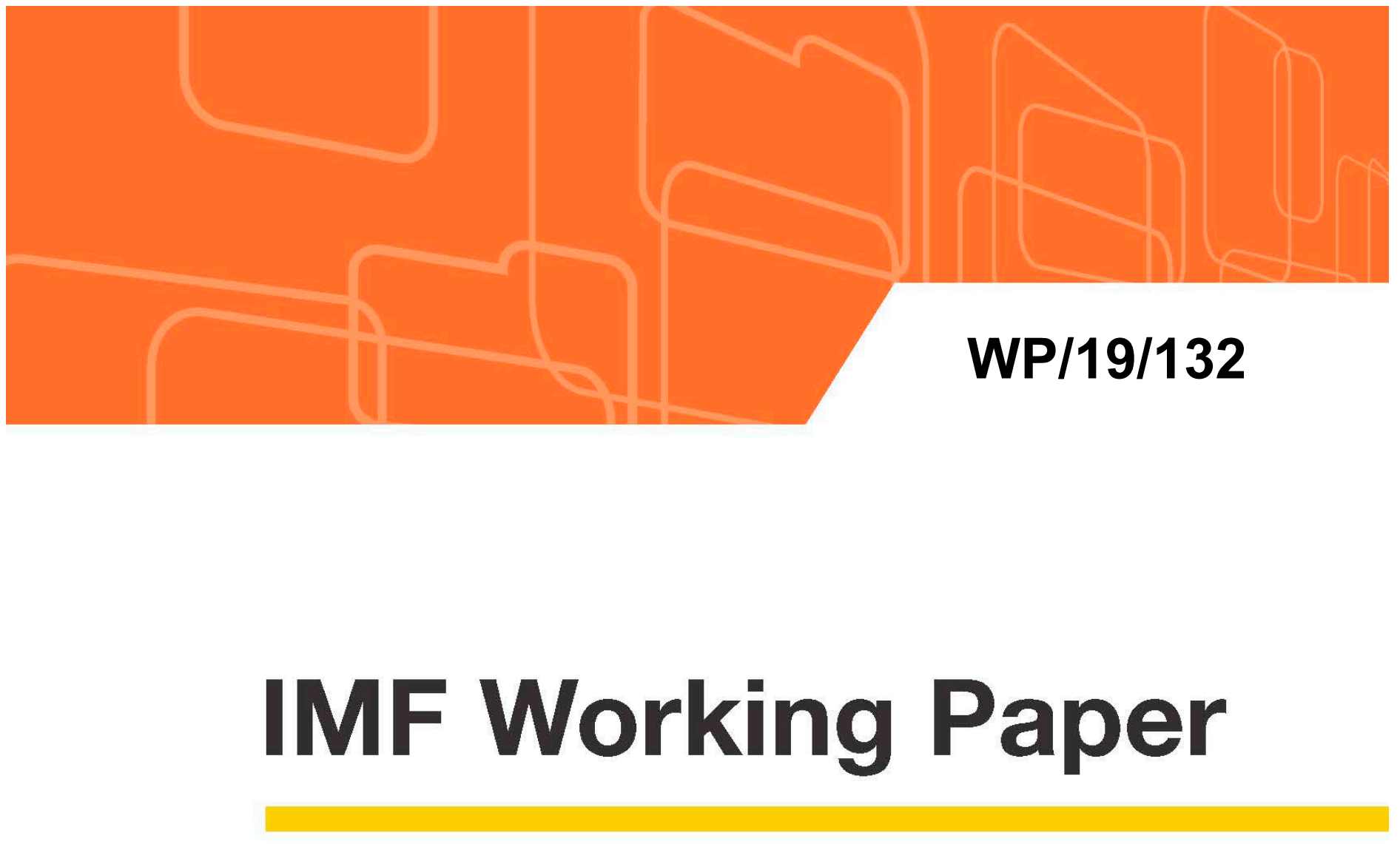

\section{The Measurement of External Accounts}

by Gustavo Adler, Daniel Garcia-Macia, and Signe Krogstrup

IMF Working Papers describe research in progress by the author(s) and are published to elicit comments and to encourage debate. The views expressed in IMF Working Papers are those of the author(s) and do not necessarily represent the views of the IMF, its Executive Board, or IMF management.

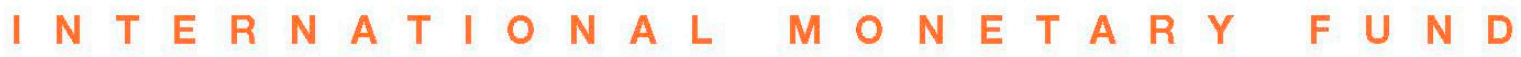




\title{
IMF Working Paper
}

\section{Research Department and European Department}

\section{The Measurement of External Accounts*}

\section{Prepared by Gustavo Adler, Daniel Garcia-Macia, and Signe Krogstrup}

Authorized for distribution by Luis Cubeddu

June 2019

\section{IMF Working Papers describe research in progress by the author(s) and are published to elicit comments and to encourage debate. The views expressed in IMF Working Papers are those of the author(s) and do not necessarily represent the views of the IMF, its Executive Board, or IMF management.}

\begin{abstract}
Growing international integration in trade and finance can challenge the measurement of external accounts. This paper presents a unified conceptual framework for identifying sources of mismeasurement of foreign investment income in current account balances. The framework allows to derive a precise definition of measurement distortions and an empirical strategy for estimating their importance. As an application, we empirically estimate two specific distortions related to inflation and retained earnings on portfolio equity for a broad set of countries. We find these may explain a non-trivial share of current account imbalances and that they are particularly relevant in countries with large external investment positions. We also discuss how merchanting and profit-shifting activities could lead to measurement distortions. We suggest areas for future research and underline the need to strengthen data collection efforts.
\end{abstract}

JEL Classification Numbers: F32, G11, G20.

Keywords: Current Account, Measurement, External Imbalances, Global Imbalances.

Authors’ E-Mail Address: GAdler@,imf.org; SKrogstrup@,imf.org; DGarciaMacia@,imf.org

\footnotetext{
* We would like to thank Gianluca Benigno, Joe Chensavasdijai, Luis Cubeddu, Mai Dao, Kevin Fletcher, Erik Frohm, Alain Gabler, Nataliya Ivanyk, Shakill Hassan, Deanie Haugaard Jensen, Hector Hernandez, Venkateswarlu Josyula, Shafik Hebous, Gian Maria Milesi-Ferretti, Maury Obstfeld, Jonathan D. Ostry, Cyril Rebillard, Marshall Reinsdorf, Carlos Sanchez Muñoz, Anna Shabunina, Pinar Yesin, and seminar participants and colleagues from the ECB, IMF, Swiss National Bank, Danmarks Nationalbank and Riksbank for helpful discussions and suggestions. Deepali Gautam provided excellent research assistance. The views in this paper are solely the responsibility of the authors and do not necessarily reflect the views of the International Monetary Fund, its Executive Management or its Board.
} 


\section{Introduction}

The increase in global external imbalances since the early 2000s has set off a large body of analytical work seeking to explain their drivers, persistence and related developments in net foreign asset positions (e.g. Dooley et al. (2004), Lane and Milesi-Ferretti (2007), Gourinchas and Rey (2007)). One strand of this literature has questioned the measurement of external imbalances, suggesting that statistical measures of current accounts may not always give an accurate picture of true external imbalances (e.g. Hausmann and Sturzenegger (2007)). ${ }^{1}$ The focus has primarily been on how financial returns on foreign investment positions are recorded in the income balance of the current account, and the empirical evidence that large and persistent valuation changes in the net international investment position (NIIP) tend to offset the impact of the current account on the NIIP for some countries (Gourinchas and Rey (2007), Obstfeld (2012), Adler and Garcia-Macia (2018)). Recent studies have pointed to specific types of measurement problems, including the omission of retained earnings from foreign portfolio equity in the income balance (Lane (2015), Mancini and Stoffels (2012), Fischer et al. (2019)) and the overestimation of real income from foreign debt holdings due to the inflation component embedded in the nominal interest payments (Fletcher (2019), Mian and Saure (2017)). These issues affect the statistical measure of the current account and NIIP valuation changes without influencing the accumulation of real external wealth. Others have pointed to the rise in global value chains, profit shifting and international merchanting activities as potentially affecting the measurement of external accounts (Fard et al. (2017)), Beusch et al. (2015)). Indeed, increasing financial and trade integration and the growing role of multinational corporations are challenging the measurement of external positions, as the boundaries between residents and non-residents and the corresponding attribution of income across countries have become more blurred (e.g. Kramp et al. (2018)). ${ }^{2}$

What constitutes a measurement distortion as opposed to a proper measure of the current account balance? While previous studies have pointed to some specific issues, as mentioned above, the economically relevant current account measure and the characteristics of statistical deviations from this measure are not well defined and understood. There is no unified conceptual framework within which these issues can be analyzed and compared. Moreover, there are no comprehensive empirical studies of the relevance of measurement distortions in driving global imbalances, both over time and cross countries. This paper

\footnotetext{
${ }^{1}$ See also Obstfeld (1986) for an early conceptual account of possible measurement issues.

${ }^{2} \mathrm{~A}$ prominent example is Ireland, where a recent shift of domicile of intangible assets held by a multinational had strong effects on Ireland's national and external accounts, without this shift representing any real changes in Irish residents' external wealth (Lane (2017)).
} 
seeks to contribute on both fronts.

We propose a conceptual framework for characterizing and defining measurement distortions. The framework builds on the work of Lane and Milesi-Ferretti (2007), Lee et al. (2008) and Fletcher (2019) although it encompasses a more general set of sources of measurement distortions. It is based on a set of accounting identities for foreign stocks (the international investment position) and flows (the balance of payments) based on the statistical definitions of external positions, and notably, the associated investment income. In addition, a minimum set of accounting equations are introduced to decompose components of equity returns, dividends and retained earnings as well as default and risk premia.

Our conceptual framework highlights two distinct types of measurement issues. The first type, which we refer to as measurement distortions, and which formed the basis of measurement refinements of the IMF's External Balance Assessment in 2018 (see Cubeddu et al. (2019)), comprises accounting treatments that shift the recording of financial returns on foreign investment positions arbitrarily between the income balance and NIIP valuation changes. A distinguishing feature is that these factors do not change the value of net foreign assets per se, but only the share that is accounted for statistically by the current account as opposed to valuation changes. We show that retained earnings on portfolio equity and interest rate compensation for expected inflation and default are included in this category. Taking the inflation distortion as an example, issuing foreign debt in a high-inflation currency entails paying a high nominal interest rate to foreign creditors, which is recorded as income. However, the real value of the debt is eroded by the high inflation rate, so the real interest payment to the foreign creditor is lower than implied by the nominal interest. This real erosion is reflected in a declining real value of foreign liabilities, which is not reflected in the income balance. The lack of accounting for the inflation erosion of the value of debt in the income statistics leads to an overestimation of outward interest payments, and an underestimation of the current account in this example. In a zero-inflation economy with the same foreign liabilities and real interest rate as an economy with positive inflation, the income balance would incorporate the full real interest payment, while the income balance of the economy with inflation would reflect the nominal value. The income balance recorded for the two economies would differ although in real terms, they are identical.

The second type of measurement issues is not a distortion per se, but definitional in nature, and we refer to it as definitional measurement issues. For the purposes of national accounting, financial income is defined as distinct from capital gains on investments. The latter are hence not included in income flow statistics. This means that returns to foreign investments driven by real exchange rates or asset prices changes, while affecting net foreign 
assets, are not recorded as investment income in the current account. When such returns are persistent, they lead to persistent valuation changes in net foreign assets. Such returns, if predictable, can be perceived by investors as income on par with recorded investment income, and can have the same impact on the investor's savings investment decisions. It remains a broader and unsettled discussion whether such definitional measurement issues should be accounted for when conducting a comprehensive assessment of a country's external balances. While our conceptual framework allows for an accurate definition and characterization of these, addressing whether definitional measurement issues should be reflected in current accounts is beyond the scope of this paper. Outright measurement distortions, on the other hand, constitute a clear departure from a real economic concept of income, and can in some cases be empirically estimated, as we show. Hence, the empirical section of this paper focuses on outright measurement distortions.

As an example of an empirical application of our conceptual framework, we attempt to quantify empirically the impact of two of the measurement distortions that we identify, namely the inflation and retained earnings distortions. We focus on these because data availability allow for reasonable empirical estimation. We carry out estimates for a broad set of countries over time. While uncertainty and noise surrounding the estimates remain high, notably reflecting data limitations, the analysis suggests that a non-trivial part of what is currently captured as current account imbalances could be linked to these measurement distortions. For example, in 2016, about 22 percent of overall current account surpluses and deficits could be due to mismeasurement according to our estimates. We also find that they are likely to be particularly relevant in countries that have large external investment positions.

Finally, the proposed conceptual framework is based on a minimal set of accounting equations, is stylized, simple and intuitive, and therefore useful for structuring thoughts about definitions of measurement. We use it to illustrate specific measurement distortions affecting external positions, but there may be others that our framework currently does not incorporate. As our understanding of measurement issues evolve, and as international trade and financial relations continue to develop, the framework can be modified and extended accordingly. Examples of emerging issues not yet reflected in the framework are the role of depreciation of foreign owned intangible assets as described in Lane (2017), and the measurement of income on FDI (Milesi-Ferretti and Lane (2017)).

The paper proceeds as follows. Section 2 presents the conceptual framework. An empirical application to the estimation of measurement distortions is presented in Section 3. Section 4 discusses other empirical issues related to measurement, including the implications of growing merchanting and profit-shifting activities. The final section concludes 
with key takeaways and the appendix contains additional information on the data.

\section{A Conceptual Framework}

Our conceptual framework is based on a set of standard balance of payments identities and accounting equations.

\subsection{Stock and Flow Identities}

Consider the nominal value of country $c$ 's net foreign asset position, $B_{c}$, expressed in domestic currency units, which can be written as:

$$
B_{c}=\sum_{j \in J} S_{c j}\left[Q_{j}\left(A_{c j}^{E Q}-L_{c j}^{E Q}\right)+\left(A_{c j}^{D}-L_{c j}^{D}\right)\right]
$$

where time subscripts have been omitted and $J$ denotes the set of all world currencies, including the domestic currency of country $c . S_{c j}$ is country $c$ 's nominal exchange rate, measured in units of currency $c$ per unit of foreign currency $j . Q_{j}$ is the price of equities issued in currency $j$ (also assumed to be issued by country $j$ ). ${ }^{3} A_{c j}^{E Q}$ and $L_{c j}^{E Q}$ denote the country $c$ 's stock of equity assets and liabilities issued in currency $j$ respectively. Similarly, $A_{c j}^{D}$ and $L_{c j}^{D}$ denote the nominal value of country $c$ 's holdings of debt assets and liabilities denominated in currency $j$. In contrast to equity, debt assets and liabilities can often be denominated in other currencies than the country's own currency.

Leaving aside errors and omissions ${ }^{4}$ and capital transfers, the balance of payments identity $(C A=F A)$ states that the net acquisition of foreign assets is equal to the balance of trade in goods and services (TB) plus the investment income balance (IB):

$$
T B_{c}+\sum_{j \in J} I B_{c j}=\sum_{j \in J} S_{c j}\left[Q_{j}\left(d A_{c j}^{E Q}-d L_{c j}^{E Q}\right)+\left(d A_{c j}^{D}-d L_{c j}^{D}\right)\right]
$$

where $d$ denotes transaction-based changes over the time period for which the current account is recorded.

Dividing all stocks and flows by nominal GDP, ${ }^{5}$ totally differentiating equation (1),

\footnotetext{
${ }^{3}$ We have no equivalent of $Q$ for debt as debt is accounted for at its notional value.

${ }^{4}$ Errors and omissions are treated as negligible. Their role in estimated current account balances is beyond the scope of this note. See related discussion in Adler and Garcia-Macia (2018).

${ }^{5}$ Formally, we are dividing by nominal GDP measured by consumer prices. This is a simplification, as empirically, we would divide by nominal GDP valued at the GDP price deflator. However, since CPI is what matters for the real exchange rate, and this in turn is what matters for the inflation distortion described below, deflating with the CPI throughout keep the derivations of the measurement issues simple. It should be kept in mind, however, that empirically, the extent to which the GDP price deflator and CPI price index differ may affect results, particularly relating to the inflation distortion.
} 
and substituting out net asset acquisitions of foreign assets using equation (2) yield an expression for the change in the net foreign asset position in percent of GDP $\left(b_{c}\right)$ over time:

$$
\begin{aligned}
d\left(b_{c}\right) & =-\left(\pi_{c}+g_{c}\right) b_{c}+\left[t b_{c}+\sum_{j \in J} i b_{c j}\right]+\sum_{j \in J}\left[\dot{s}_{c j} b_{c j}+\dot{q}_{j} b_{c j}^{e q}\right]+o c_{c} \\
& \equiv-\left(\pi_{c}+g_{c}\right) b_{c}+c a_{c}+v_{c}+o c_{c}
\end{aligned}
$$

with the following notation and definitions:

$$
\begin{aligned}
& b_{c}=\quad \frac{B_{c}}{P_{c} G D P_{c}} \quad \text { NFA, GDP share } \\
& \pi_{c}=\quad \frac{d P_{c}}{P_{c}} \quad \text { Change in the CPI of country } \mathrm{c} \\
& \pi_{j}=\quad \frac{d P_{j}}{P_{j}} \quad \text { Change in CPI of country } j \\
& g_{c}=\quad \frac{d G D P_{c}}{G D P_{c}} \quad \text { Real GDP growth rate } \\
& \dot{s}_{c j}=\quad \frac{d S_{c j}}{S_{c j}} \quad \text { Rate of change in value of currency } \mathrm{j} \\
& \dot{q}_{j}=\quad \frac{d Q_{j}}{Q_{j}} \quad \text { Change in equity prices of country } j \\
& b_{c j}^{e q}=\frac{S_{c j} Q_{j}\left(A_{c j}^{e q}-L_{c j}^{e q}\right)}{P_{c} G D P_{c}} \quad \text { Net foreign equity claims in currency j, GDP share } \\
& b_{c j}^{d}=\quad \frac{S_{c j}\left(A_{c j}^{d}-L_{c j}^{d}\right)}{P_{c} G D P_{c}} \quad \text { Net foreign debt claims in currency } \mathrm{j} \text {, GDP share } \\
& b_{c j}=\quad b_{c j}^{e q}+b_{c j}^{d} \quad \text { Net foreign assets in currency } \mathrm{j} \text {, GDP share } \\
& t b_{c}=\quad \frac{T B_{c}}{P_{c} G D P_{c}} \quad \text { Balance of goods, services, transfers, GDP share } \\
& i b_{c}=\quad \frac{I B_{c}}{P_{c} G D P_{c}} \quad \text { Income balance vis-à-vis country } j \text {, GDP share } \\
& c a_{c}=\quad t b_{c}+\sum_{j \epsilon J} i b_{c j} \quad \text { Current account balance, GDP share } \\
& v_{c}=\sum_{j \epsilon J}\left[\dot{s}_{c j} b_{c j}+\dot{q}_{j} b_{c j}^{e q}\right] \quad \text { Valuation gains on NFA, GDP share } \\
& o c_{c} \quad \text { Other changes in NFA, GDP share }
\end{aligned}
$$

Since income from direct and portfolio equity investments are treated differently for statistical purposes (as discussed in detail below), we allow equity investments to take the form of foreign direct equity investments (fdi) and portfolio equity investments (peq):

$$
b_{c j}^{e q}=b_{c j}^{f d i}+b_{c j}^{p e q}
$$

The investment income balance is defined, in line with the statistical definition of 
income, as the sum of nominal, transacted, income streams associated with the net asset position. Divide the equity position into foreign direct equity investments (fdi) and portfolio equity investments (peq). The income balance can be written as:

$$
i b_{c}=\sum_{j \in J} i b_{c j}=\sum_{j \in J}\left(i_{j}^{f d i} b_{c j}^{f d i}+i_{j}^{p e q} b_{c j}^{p e q}+i_{j}^{d} b_{c j}^{d}\right)
$$

where $i_{j}^{f d i}, i_{j}^{p e q}$ and $i_{j}^{d}$ are the accrued income on bilateral net foreign direct equity, net portfolio equity and net debt positions, respectively, all in currency $j$.

Inserting expression (6) into expression (3) yields:

$$
\begin{gathered}
d\left(b_{c}\right)=\left[-\left(\pi_{c}+g_{c}\right) b_{c}\right]+\left[t b_{c}+\sum_{j \epsilon J}\left(i_{j}^{f d i} b_{c j}^{f d i}+i_{j}^{p e q} b_{c j}^{p e q}+i_{j}^{d} b_{c j}^{d}\right)\right] \\
+\sum_{j \epsilon J}\left[\dot{s}_{c j} b_{c j}+\dot{q}_{j}\left(b_{c j}^{f d i}+b_{c j}^{p e q}\right)\right]+o c_{c}
\end{gathered}
$$

where the first term on the right hand side shows the mechanical impact of nominal GDP growth on the NFA to GDP ratio, the second term is the current account balance, and the third term represents NFA valuation gains. This decomposition is consistent with the statistical definition of the current account balance, where $i$ 's are nominal income accrued on foreign assets and liabilities.

\subsection{Returns on Debt and Equity}

To illustrate how the treatment of interest income and retained earnings (i.e. dividend policies) on cross-border portfolio equity affects the statistical measure of the current account and, in turn, NIIP valuation changes, we first characterize cross border income on debt and equity instruments following the statistical principles for income recording. According to IMF (2009), the statistical measure of foreign investment income is nominal and based on recorded transactions, or contractual. It generally does not include returns on investments which are not paid out and recorded as part of a formal agreement for the remuneration of assets. ${ }^{6}$ The statistical income balance thus records nominal interest and dividend payments.

\subsubsection{Return on Debt}

Returns on debt can be thought of as consisting of a real and a nominal component in line with the Fisher equation. To get at the empirically important component of risk premiums

\footnotetext{
${ }^{6}$ There are other exceptions to this. Income on debt securities are not just the recorded coupon payments, but also the accrued interest in the case of zero coupon debt.
} 
in yields, we introduce default risk and a risk premium into the Fisher equation. These components have implications for the measurement of the current account.

Assume that the rate of default on country $j$ securities is $\lambda_{j}$. Investors have expectations about the rate of inflation and default and factor these into their investment decisions, requiring compensation for the associated expected losses as well as for taking on the risk associated with their uncertainty. The extended Fisher equation can thus be written as:

$$
i_{j}^{d}=r_{j}+\pi_{j}^{e}+\lambda_{j}^{e}+r p_{j}^{e} \text { for all } j \epsilon J
$$

where $r_{j}$ is the real interest rate; $\pi_{j}^{e}$ denotes inflation expectations; and $\lambda_{j}^{e}$ is the expected rate of default on debt securities issued by country $\mathrm{j}$, satisfying $\lambda_{j}=\lambda_{j}^{e}+\epsilon_{j}^{\lambda}$ and where $\epsilon_{j}^{\lambda}$ is a zero mean random shock. Similarly, deviations of realized inflation from expected inflation are characterized by $\pi_{j}=\pi_{j}^{e}+\epsilon_{j}^{\pi}$, where $\epsilon_{j}^{\pi}$ is a zero mean random shock. Finally, $r p_{j}^{e}$ is a risk premium that compensates investors for taking on risk, notably associated with stochastic inflation and default rates, and is a function of risk aversion as well as the variances of shocks (we which do not further specify here).

Define country c's bilateral real exchange rate vis-a-vis country $j$ as $\rho_{c j} \equiv \frac{S_{c j} P_{j}}{P_{c}}$, where $S_{c j}$ is the bilateral nominal exchange rate and $P_{j}$ and $P_{c}$ are the price levels in countries $j$ and $c$, respectively. It follows that:

$$
\dot{s}_{c j}=\pi_{c}-\pi_{j}+\dot{\rho}_{c j}
$$

where $\dot{\rho}_{c j}$ is the rate of change of the real exchange rate. Further, assume that real exchange rate changes consist of an expected rate of change and a random zero-mean shock:

$$
\dot{\rho}_{c j}=\dot{\rho}_{c j}^{e}+\epsilon^{\rho}
$$

where $\dot{\rho}_{c j}^{e}$ is the expected real rate of change of currency c against currency $\mathrm{j}$, and $\epsilon_{j}^{\rho}$ is a zero-mean random shock to the exchange rate.

Inserting in (9) yields:

$$
\dot{s}_{c j}=\pi_{c}^{e}+\epsilon_{c}-\pi_{j}^{e}-\epsilon_{j}+\dot{\rho}_{c j}^{e}+\epsilon^{\rho}
$$

\subsubsection{Return on Equity}

Another aspect requiring some structure relates to the return on equity. IMF (2009) describes the statistical principles for how income on equity is recorded. These principles include different treatments for income on directly owned and portfolio owned equity, as 
discussed below. We stay as close as possible to those principles here, while we abstract from issues related to corporate taxes and depreciation of capital.

Consider first the income on portfolio equity and denote distributed dividends on portfolio capital invested in firms in country $j$ by $d i v_{j}^{p e q}$, gross earnings by $g e_{j}$, and retained earnings by $r e_{j}$, all as a share of portfolio capital invested in country $j$ firms, $A_{j}^{P E Q}{ }^{7}$ The dividend yield on portfolio equity issued by country $j$ (in currency $j$ ) is then given by:

$$
d i v_{j}^{p e q}=g e_{j}-r e_{j}
$$

The statistical definition of income on portfolio equity is equal to distributed dividends, as these give rise to a recorded transaction, $i_{j}^{p e q}=d i v_{j}$. Retained earnings, on the other hand, are not recorded as income on portfolio equity. Suppose further that retained earnings are kept as cash in the firm, adding one-for-one to the value of the firm. ${ }^{8}$ Other things equal (e.g., assuming that firms do not issue new equity or increase leverage) a change in the nominal market value of firms is equal to the change in the portfolio equity price, $\dot{q}_{j}^{p e q}$. The latter can be decomposed into a term reflecting inflation, a one-for-one increase in the real value of the firm due to retained earnings, and any residual real equity price increases that go beyond these other factors: ${ }^{9}$

$$
\dot{q}_{j}^{p e q}=\pi_{j}+r e_{j}+\hat{q}_{j}
$$

where $\hat{q}_{j}$ captures other real equity price gains, and $r e_{j}+\hat{q}_{j}$ constitute total real equity price changes. We allow other real equity price gains to be non-zero in expectation:

$$
\hat{q}_{j}=\hat{q}_{j}^{e}+\epsilon_{j}^{q}
$$

where we for simplicity treat $\hat{q}_{j}^{e}$ as a constant that can be both positive and negative, and where $\epsilon_{j}^{q}$ is a random shock to equity prices with a zero mean.

Now consider returns to directly owned equity. The statistical definition of income on foreign direct equity investments is equal to total earnings including retained earnings, $i_{j}^{f d i}=g e_{j}$. The logic behind this differential statistical treatment vis-a-vis portfolio equity is that retained earnings are considered undertaken by agreement from direct owners, and hence contractual. This is not the case for portfolio shareholders. While this follows statis-

\footnotetext{
${ }^{7} \mathrm{An}$ implicit assumption in the framework is that dividends move along with inflation, as opposed to ex-ante contracted nominal interest payments.

${ }^{8}$ Retained earnings could also be used to make new investments. If Tobin's q is equal to one, this would equally increase the value of the firm by the value of the retained earnings.

${ }^{9}$ Such changes could reflect a discounting of expected future productivity growth, market portfolio balance effects on equity prices, an equity risk premium.
} 
tical principles, its economic rationale is less clear, as retained earnings are income for the ultimate foreign owner in both cases. This differential treatment results in a measurement distortion related to retained earnings on portfolio equity, as further explained below.

Retained earnings on foreign direct investment are instead captured in the balance of payments as new foreign direct equity capital, or a capital flow, $d A_{j}^{F D I}=r e_{j} A_{j}^{F D I}$. Retained earnings hence do not contribute as a capital gain but rather as new investment flow, that is, a financial account transaction.

As before, assuming that directly owned foreign firms do not issue new equity or increase leverage, a change in the market value of a directly owned initial capital stock of the foreign firms is equal to the rate of change in the equity price, $\dot{q}_{j}^{f d i}$. This rate of change can be decomposed into an increase in nominal value due to inflation and any other real equity price increases: ${ }^{10}$

$$
\dot{q}_{j}^{f d i}=\pi_{j}+\hat{q}_{j}
$$

\subsection{Statistical Versus Economic Measures of the Current Account}

Making use of the above expressions, the statistical definition of the income balance can be written as:

$$
i b_{c}^{s t a t}=\sum_{j \in J}\left(g e_{j} b_{c j}^{f d i}+\left(g e_{j}-r e_{j}\right) b_{c j}^{p e q}+\left(r_{j}+\pi_{j}^{e}+\lambda_{j}^{e}+r p_{j}^{e}\right) b_{c j}^{d}\right) .
$$

Furthermore, combining equations (7), (8), (9), (13) and (16) and rearranging yields the decomposition of changes in the NFA ratio into components consistent with the statistical definition of the current account:

$$
d\left(b_{c}\right)=-g_{c} \cdot b_{c}+c a_{c}^{s t a t}+v_{c}^{s t a t}+o c_{c}
$$

where $c a_{c}^{\text {stat }}$ is the statistical definition of the current account and $v_{c}^{\text {stat }}$ are the valuation changes in the NIIP that result from the statistical treatment of the current account. Specifically:

$$
\begin{gathered}
c a_{c}^{s t a t}=t b_{c}+\sum_{j \epsilon J}\left(g e_{j} b_{c j}^{e q}-r e_{j} b_{c j}^{p e q}+\left(r_{j}+\pi_{j}^{e}+\lambda_{j}^{e}+r p_{j}^{e}\right) b_{c j}^{d}\right) \\
v_{c}^{\text {stat }}=\sum_{j \epsilon J}\left[\left(\epsilon^{\rho}+\dot{\rho}_{c j}^{e}\right) b_{c j}+\left(\epsilon_{j}^{q}+\hat{q}_{j}^{e}\right) b_{c j}^{e q}+r e_{j} b_{c j}^{p e q}-\left(\epsilon_{j}^{\pi}+\epsilon_{j}^{\lambda}+\pi_{j}^{e}+\lambda_{j}^{e}\right) b_{c j}^{d}\right]
\end{gathered}
$$

\footnotetext{
${ }^{10}$ To simplify, we further assume that other real equity price changes are the same across directly owned and portfolio owned equity as described in equation (14).
} 
where all random variables are divided into their expected means and random zero-mean shock components.

Meanwhile, an economic measure of the current account that captures real income (and the related accumulation of real wealth) could be defined as:

$$
c a_{c}^{e c o n}=t b_{c}+\sum_{j \epsilon J}\left(g e_{j} b_{c j}^{e q}+\left(r_{j}+r p_{j}^{e}\right) b_{c j}^{d}\right)
$$

where all equity earnings are included, while only the real interest rate and the risk premium are included as part of the financial return. Equation (21) shows that there are remaining sources of predictable real returns to foreign investments which are not captured in this economic definition of the current account, but instead are reflected in valuation changes. These are expected real exchange rate changes $\left(\dot{\rho}_{c j}^{e}\right)$ affecting all foreign currency denominated positions, and expected real increases in equity prices $\left(\hat{q}_{j}^{e}\right)$ affecting foreign equity positions. ${ }^{11}$ We refer to such measurement issues as definitional. A broader economic definition of the income balance could include such definitional measurement issues on par with outright distortions, but it is not clear that this would be economically correct or desirable. ${ }^{12}$ It follows that the economically concept of NIIP valuation changes is given by

$$
v_{c}^{e c o n}=\sum_{j \epsilon J}\left[\left(\epsilon^{\rho}+\dot{\rho}_{c j}^{e}\right) b_{c j}+\left(\epsilon_{j}^{q}+\hat{q}_{j}^{e}\right) b_{c j}^{e q}-\left(\epsilon_{j}^{\pi}+\epsilon_{j}^{\lambda}\right) b_{c j}^{d}\right]
$$

Rearranging equations (18), (19), (20) and (21) yields the following system of equations:

$$
\begin{aligned}
& c a_{c}^{\text {stat }}=c a_{c}^{e c o n}-M_{c}^{e c o n} \\
& v_{c}^{\text {stat }}=v_{c}^{e c o n}+M_{c}^{e c o n}+\mu_{c} \\
& d\left(b_{c}\right)=-g_{c} \cdot b_{c}+c a_{c}^{e c o n}+\mu_{c}+o c_{c}
\end{aligned}
$$

where measurement distortions (i.e., differences between the statistical and economic con-

\footnotetext{
${ }^{11}$ The latter could for example reflect the equity risk premium.

${ }^{12}$ One way of defining economic concepts of the current account reflecting predictable valuation changes in the income balance could be:

$$
\begin{gathered}
c a_{c}^{e c o n *}=t b_{c}+\sum_{j \epsilon J}\left(\dot{\rho}_{c j}^{e} b_{c j}+\left[g e_{j}+\hat{q}_{j}^{e}\right] b_{c j}^{e q}+\left(r_{j}+r p_{j}^{e}\right) b_{c j}^{d}\right) \\
v_{c}^{e c o n *}=\sum_{j \epsilon J}\left[\epsilon^{\rho} b_{c j}+\epsilon_{j}^{q} b_{c j}^{e q}-\left(\epsilon_{j}^{\pi}+\epsilon_{j}^{\lambda}\right) b_{c j}^{d}\right]
\end{gathered}
$$

Under this definition, there are no remaining predictable components in NIIP valuation changes, which hence would have a mean expected value of zero. Implementing this economic definition, however, would be very challenging as it would require estimating the predictable components of NIIP valuation changes. This is an avenue for future research.
} 
cepts) and the remaining random NIIP changes are given by:

$$
\begin{aligned}
& M_{c}^{e c o n}=\sum_{j \in J}\left[r e_{j} b_{c j}^{p e q}-\left(\pi_{j}^{e}+\lambda_{j}^{e}\right) b_{c j}^{d}\right], \\
& \mu_{c}=\sum_{j \in J}\left[\epsilon^{\rho} b_{c j}+\epsilon_{j}^{q} b_{c j}^{e q}-\left(\epsilon_{j}^{\pi}+\epsilon_{j}^{\lambda}\right) b_{c j}^{d}\right] .
\end{aligned}
$$

The above expressions allow us to characterize different types of measurement distortions when applying a statistical definition of the current account. We have taken into account specific issues that are currently well understood, but simplified the framework in other dimensions, such as differential tax treatment of different types of income flows, to allow for tractability. The framework can be further adapted and extended to future developments in our understanding of what drives cross border transactions and how these relate to measures of current account.

\subsection{Measurement Distortions}

The system of equations above shows these measurement issues, captured in $M_{c}$, are associated with one-for-one shifts between the income balance and NIIP valuation changes, and cancel out if the income balance and valuation changes are consolidated. They are associated primarily with how the financing of new equity is structured (i.e., extent of retained earnings), the recording of nominal (as opposed to real) returns to investment, and the treatment of default risk. These factors affect the measurement of the income balance and hence the current account without having a clear economic equivalent or interpretation. We discuss each of these below.

\subsubsection{The Inflation Distortion}

A country $j$ with high expected inflation will have a commensurately high nominal interest rate to compensate investors for the expected erosion of the real value of the principal. Nominal interest payments provide a biased measured of real income (upward or downward, depending on the sign of $b_{c j}^{d}$ - that is, whether country $c$ has a positive or negative net position in currency $j$ denominated fixed income securities). As also shown in Fletcher (2019) and Mian and Saure (2017), this statistical treatment leads to a systematic offsetting component $\left(\pi_{j}^{e} b_{c j}^{d}\right)$ in NIIP valuation gains, as can be seen from comparing the role of inflation in the expressions (18) and (19). That is, two identical economies that are only distinguished by having different degrees of exposure to currencies with different associated inflation rates (but equal real rates) would have different statistical measures of their 
current accounts, and hence valuation changes, due to this treatment of inflation in the statistical definition of income. ${ }^{13}$ The inflation distortion is well-recognized in national accounting. ${ }^{14,15}$

Denote by $I E_{c}$ the amount by which the statistical definition of the income balance overestimates real returns to investment due purely to compensation for expected inflation erosion. IE is given by:

$$
I E_{c}=\sum_{j \in J} \pi_{j}^{e} b_{c j}^{d} .
$$

Expression (27) shows that net debt positions in different currencies as well as bilateral inflation differentials affect the sign and size of $I E_{c}$. For example, if countries borrow mainly in their own currency and lend a largely equal amount in foreign currency, the inflation differential vis-a-vis the rest of the world will dictate the sign of the inflation distortion, and the net position in the given currency will dictate its size. A low-inflation country with these features would hence tend to have positive inflation distortion, i.e. the statistical current account measure would tend to overestimate the economic current account. When countries borrow in foreign currency or have large net debt positions, however, this does not necessarily hold true.

\subsubsection{The Retained Earnings Distortion}

As discussed above, the income balance includes distributed dividends by foreign-owned companies, but it does not include the share of foreign portfolio owned companies' earnings which are retained and hence not resulting in a transaction of income to owners. Retained earnings are either reinvested or held as cash, in either case leading to a commensurate increase in the value of the investment that shows up as a systematic component of valuation changes in the NIIP, as shows in expression (19) and as shown in Mancini and Stoffels (2012) and Fischer et al. (2019). As retained earnings are inversely proportional to distributed dividends, an increase in this component leads to a one-for-one shift from the income balance to valuation changes in the NIIP, as comparing the role of $r e_{j}$ in expressions (18) and (19) shows. Instead of retaining earnings, a company could finance itself by issuing new equity or taking up debt, while distributing all current earnings. In the latter case,

\footnotetext{
${ }^{13}$ Inflation differentials would be reflected one-for-one in exchange rate depreciation expectations, which is another way of seeing the inflation distortion.

${ }^{14}$ See, for example, Jump (1980), Vanoli (1999) and Hill and Hill (2003) for a discussion of the inflation distortion in the context of national account statistics.

${ }^{15}$ The unexpected component of inflation is treated as a valuation gain under both definitions. It is still debated in the literature whether it should be corrected for or not, however. See, for example, Vanoli (1999) and Hill and Hill (2003).
} 
the income balance would reflect all earnings. ${ }^{16}$ The retained earnings distortion does not apply to direct investment.

Similar to the case of inflation, the magnitude of this distortion is proportional to the size of gross portfolio equity positions, and the share of earnings on foreign portfolio equity which is retained:

$$
R E_{c}=\sum_{j \in J}-r e_{j} b_{c j}^{p e q}
$$

A country with a large gross foreign portfolio equity asset position would tend to have income recorded in the income balance underestimating the true returns on these positions. Hence, the statistical measure of the current account would tend to underestimate the economic current account. Large gross portfolio equity liabilities positions instead suggest current account overestimation. Gross positions matter beyond net positions to the extent that the share of retained earnings differ across asset and liabilities positions.

It is important to note that there is no measurement distortion on retained earnings of investment fund shares as they are treated similarly to FDI, as distributed to their owners and reinvested back in the balance of payments and national accounting. ${ }^{17}$

The retained earnings distortion has potential implications beyond external accounts, as it could equally apply to accounting for domestic-to-domestic income flows. This would have implications for the extent to which corporate savings are instead accounted for as income of owners. This topic goes beyond the scope of this paper but is worth exploring in the context of revisions to national accounting, see also Reinsdorf and Nakamura (2017).

\subsubsection{The Expected Default Rate Distortion}

The conceptual framework allows us to identify a new measurement distortion, namely the default risk distortion, also discussed in Reinsdorf and Nakamura (2017). Ex-ante compensation for default risk $\left(\lambda_{j}^{e}\right)$ is recorded in the income balance, as it is part of the nominal interest on debt instruments, but the associated capital losses are not as these do not amount to agreed transactions. The latter are, instead, reflected as NIIP valuation losses and gains (depending on who the creditor is). This measurement issue is conceptually identical to the issue of inflation. A bond can lose value with positive mean expectation through inflation erosion of the value of real debt, or by default. These erosions of real value carry the same real loss for the investor, and the demand for compensation should be the same. In both cases, the erosion of real value will be reflected in valuation losses while

\footnotetext{
${ }^{16}$ This choice of financing of new investments will likely depend on institutional and tax factors.

${ }^{17}$ IMF (2009).
} 
the compensation for these losses will be reflected in the income balance, leading to an overestimation of returns to foreign debt securities. This measurement distortion is given by:

$$
D I_{c}=\sum_{j \in J} \lambda_{j}^{e} b_{c j}^{d}
$$

An important conceptual aspect is that the debt risk premia related to the second moment of the financial return (beyond the mean default rate and inflation expectations), $r p_{j}$, does not necessarily give rise to measurement issues as there is no corresponding offset in NIIP valuation changes.

\subsection{Definitional Measurement Issues}

As noted earlier, there are broader definitional measurement issues related to the treatment of expected valuation changes, including the expected equity price changes $\left(\hat{q}_{j}^{e}\right)$ and expected real exchange rate changes $\left(\dot{\rho}_{c j}^{e}\right) .{ }^{12}$ These issues touch on the question of where it is meaningful to draw the line between what should considered as income on assets and what should be considered as pure valuation changes. This question goes beyond the scope of this paper, and is an area in which further analysis is needed (see also Adler and Garcia-Macia (2018)).

\section{Empirical Application}

In this section, as an application, we carry out an empirical estimation of two measurement distortions, namely the retained earnings distortion of income on portfolio equity and the inflation distortion of debt income. Data limitations prevent us from reasonably estimating the distortion related to expected default rates. Specifically, estimating ex-ante compensation for default risk requires a reasonably accurate empirical measure of the default risk component in interest rates on debt held cross border, and such a measure is not currently available. $^{18}$

\footnotetext{
${ }^{18}$ Constructing such a measure is highly complicated by data constraints. The potentially most direct measure of the default premium, credit default swaps (CDS), is problematic because it applies to securities traded in secondary markets, potentially by foreigners, while the relevant measure in terms of national income are rates at issuance. This is particularly relevant around default episodes, where CDS implied default rates spike, while the sovereign rarely would debt during such episodes, paying such high rates. Alternatively, default premia might be estimated as the difference between effective interest rates paid on public debt and the interest rate swap on fixed rates of a similar maturity. However, this method is also highly imperfect. First, swaps for comparable maturities are not always available. Second, the debt rates would also reflect non-reserve-currency debt, which should in principle be free from default risk, and would not apply to private sector debt. Third, the differential might only capture a fraction of the default premium in countries where high swaps rates reflect compensation for short-run interest rate volatility,
} 
We discuss next the strategy for empirically estimating the two measurement distortions, after which we illustrate results. All data sources and definitions are summarized in Appendix Table 1.

\subsection{Empirical Estimation Strategy}

\subsubsection{The Retained Earnings Distortion}

Retained earnings on portfolio equity can be estimated using international investment income and stock positions, together with financial market data on average earnings and dividends for equities listed in national stock markets, as well as data on bilateral country exposures to portfolio equity. The approach entails using available aggregate stock market data and assuming that the portfolio breakdown of stocks included in cross-border portfolio equity investments is similar to the national average. We consider three different approaches described below. In all these approaches, we adjust the data on equity stocks and flows so that they are net of stock and income on investment fund shares. ${ }^{19}$

The flow approach relies on recorded income streams on foreign portfolio equity positions to reflect distributed dividends. Using stock market data on dividend yields and price earnings ratios by country allows to compute an estimate of total earnings and, in turn, retained earnings. Specifically, data on average dividend-yield and price-earnings (PE) ratios is applied to the recorded investment income on portfolio equity assets $\left(i A^{P E Q}\right)$ and liabilities $\left(i L^{P E Q}\right)$ to obtain an estimate of the unrecorded retained earnings in country c:

$$
R E_{c}=r e_{W} i A_{c}^{P E Q}-r e_{c} i L_{c}^{P E Q}
$$

$i A_{c}^{P E Q}$ and $i L_{c}^{P E Q}$ are observed income flows from assets and liabilities positions in portfolio equity for country c, retained earnings on equity issued by country c firms is given by $r e_{c}=\frac{1}{d y_{c} P E_{c}}-1$, and $d y_{c}$ and $P E_{c}$ are the dividend yield (or dividend price ratio) and the price earnings ratios in country c. $r e_{W}$ is the average retained earnings weighted by the portfolio equity asset bilateral country exposures of country c. The dividend yield and price earnings ratios are based on averages for country $\mathrm{j}$ stock markets and retrieved from Datastream. ${ }^{20}$

on top of the pure term premium.

${ }^{19}$ Data on the share of portfolio equity holdings which is not in investment funds is used to adjust all stock and flow data pertaining to cross border equity. The share is assumed to be 1 for country-years with missing data. In the flow method, the equity share is applied to the total "income balance from equity and investment funds". In the Stock method, the share is applied to the "total portfolio equity investment' positions. The Hybrid method uses the adjusted equity income and investment positions obtained from the abovementioned approaches.

${ }^{20} \mathrm{~A}$ possible alternative source of data would be sectoral distribution of income accounts. These also cover data for unlisted firms, which may or may not be relevant in cross border equity holdings. Sectoral income 
The stock approach instead relies on data on gross portfolio investment positions and stock market data on price to earnings ratios to provide an estimate of total earnings. Multiplying total earnings by stock market data on the dividend yield gives an estimate of distributed dividends. The difference between the two gives an estimate of retained earnings. Specifically, the price-earnings ratio is applied to portfolio equity asset $\left(A^{P E Q}\right)$ and liability $\left(L^{P E Q}\right)$ stock positions according to:

$$
R E_{c}^{\prime}=\operatorname{rep}_{W} A_{c}^{P E Q}-\operatorname{rep}_{c} L_{c}^{P E Q}
$$

where $r e p_{c}=\frac{1}{P E}-d y_{c}$ and $r e p_{W}$ is defined in the same way as $r e_{w}$ above.

The hybrid approach relies on international portfolio equity income flows to capture distributed dividends, while international portfolio stock positions and financial market data on price earnings ratios provide estimates of total earnings. The difference reflects retained earnings. Specifically, data on average price-earnings ratios are applied to portfolio equity asset and liability positions, and investment income is netted out:

$$
R E_{c}^{\prime \prime}=\frac{A_{c}^{P E Q}}{P E_{W}}-\frac{L_{c}^{P E Q}}{P E_{c}}-\left(i A_{c}^{P E Q}-i L_{c}^{P E Q}\right) .
$$

The advantage of this approach is that it takes maximum advantage of observed data on external income and stock positions, thereby minimizing the reliance on stock market data. The drawback is that the estimates of earnings and distributed dividends rely on different sources, and may hence be less consistent. For the purposes of this paper, we use the average across the three estimation methods discussed.

\subsubsection{The Inflation Distortion}

The inflation distortion is estimated using actual data provided by authorities or estimates of the currency composition of international debt positions and inflation rates. Inflation income in country $\mathrm{c}$ is equal to the expected inflation rate associated with each currency $\mathrm{j}$ times the net debt position $(N D)$ in each currency:

$$
\pi_{c}^{i n c o m e}=\sum_{j} \pi_{j} N D_{c j}
$$

where $\pi_{j}$ is the inflation rate in currency $\mathrm{j}$ and $N D_{c j}$ is country c's net foreign debt position denominated in currency $\mathrm{j}$ (where the currencies included under the index $\mathrm{j}$ include the domestic currency c). Annual inflation rates from International Financial Statistics are

accounts are not available on a cross country comparable format for as large a set of countries as stock market data provide. 
used.

We approximate expected inflation by a 5-year moving average of past realized inflation rates. For currency weights in international debt positions, country authorities' data are used, when available. Otherwise, we use the estimates provided by Benetrix et al (2015). Off-balance sheet currency exposures may look very different from on-balance sheet exposures. The total exposure including both on and off-balance sheet would be the relevant measure for the inflation distortion. Data are not available on off-balance sheet currency exposures in cross border positions, however. This limitation should be kept in mind as a source of uncertainty surrounding the resulting estimates. Data on gross foreign debt positions are from the External Wealth of Nations database (Lane and Milesi-Ferretti (2007)).

\subsection{Estimated Distortions and Current Account Imbalances}

Following the estimation methods described above, retained earnings and inflation distortions are computed for the 28 largest economies, representing around 85 percent of world GDP, for the period 1994-2016. ${ }^{21}$ Data limitations prevent us from considering a larger share of the global economy in our sample. That some countries which are counterparties to cross border financial operations with the sample countries are left out may give rise to some uncertainty and may explain why our parts of our estimated distortions do not cancel out across countries in our sample, as shown below. ${ }^{22}$ This should be kept in mind when interpreting the findings.

Figure 1 shows that accounting for the two measurement distortions does not fundamentally change the overall picture of current account imbalances in our sample. However, the estimates suggest they may account for a non-trivial share of imbalances. On average across countries in any given time period, the distortions appear to contribute to an overestimation of imbalances, i.e., true imbalances may be smaller than suggested by existing current account statistics. For example, in 2016, about 22 percent of overall current account surpluses and deficits appear to be related to mismeasurement according to our estimates. Moreover, the importance of the distortions appears to have grown over time, consistent with increased global integration in trade and finance, as further discussed below. Both forms of measurement distortions show an increase over time, although the

\footnotetext{
${ }^{21}$ These are the economies also included in the IMF's External Sector Report, for which data availability is adequate for the purposes of this paper. We have excluded Ireland. Despite the prominence of measurement issues of the case of Ireland, data limitations prevent the implementation of the estimation methods described in this paper. See also Box 1.2 in IMF (2017).

${ }^{22}$ If our estimated distortions were highly accurate and we were able to include all countries in the world, the total world distortion would be zero.
} 


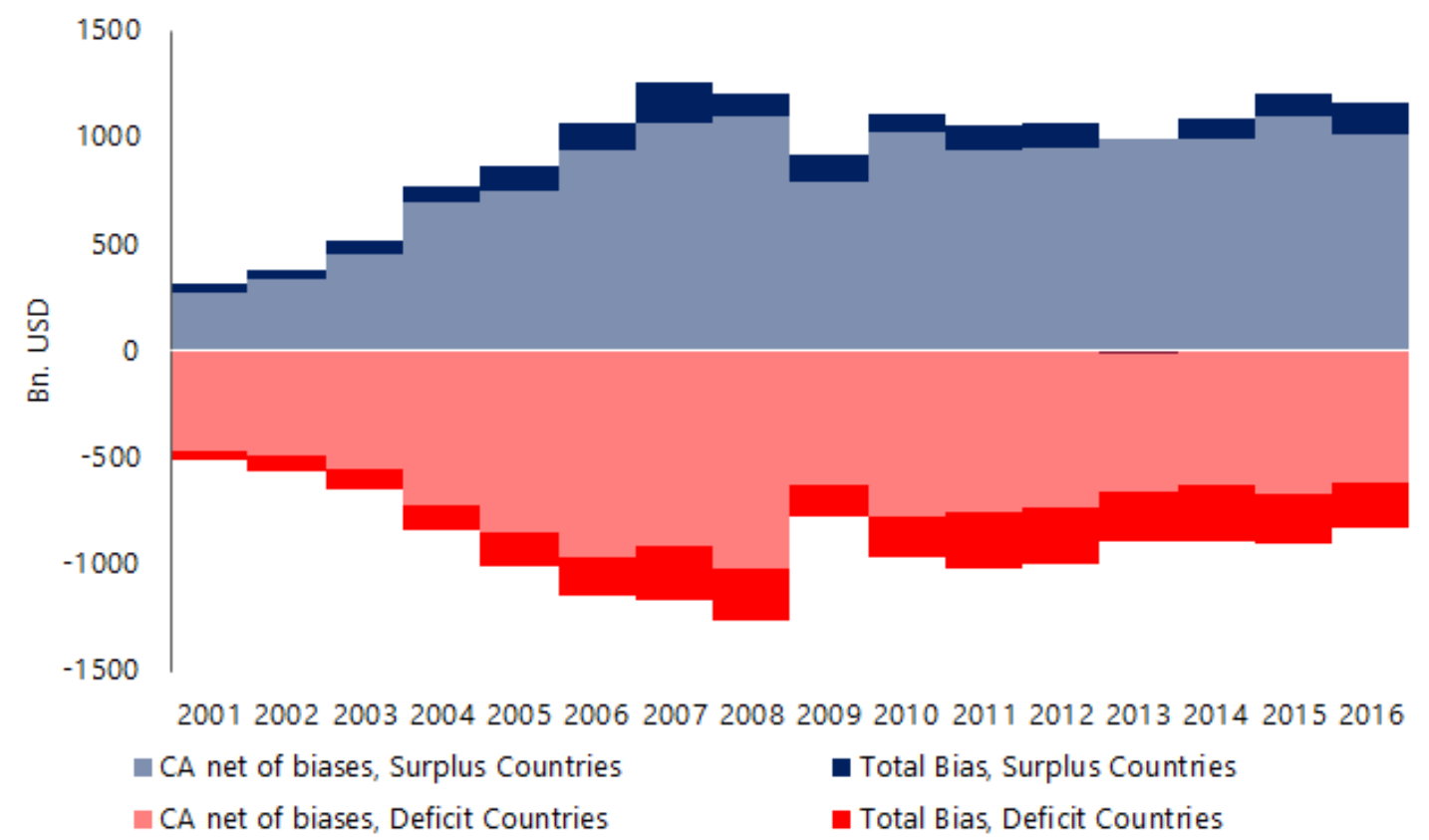

Figure 1: Global Current Account Balances and Measurement Distortions

Sources: Thomson Reuters, Wealth of Nations Database, Currency Weights Database from Benetrix, Lane and Shambaugh (2015), Country Authorities, IMF's IFS Database, IMF's WEO Database, IMF's BOP Database, IMF's CPIS Database and Fund Staff Calculations. Note: For each group, Actual CA = CA net of Distortion + Total Distortion. The sample includes ESR countries.

inflation distortion appears to be a significantly larger source of mismeasurement (Figure 2).

Figures 1 and 2 also show that the total size of the distortions in the deficit countries is larger than the total distortion in surplus countries. If our sample was truly representing a closed system, this should not be possible, but a non-trivial share of the global economy is missing due to data limitations. Notably, several small open financial centers that typically run large current account surpluses are not included, due to data constraints. ${ }^{23}$

The cross-section snapshots for the last 5 years of the sample (2012-16) depicted in Figures 3 and 4 underscore the cross-country variation in the distribution of measurement distortions. Estimates of the retained earnings distortion point to sizable mismeasurement. On one side of the spectrum are countries such as Korea, Russia and Switzerland where the retained earnings distortion leads to an overvaluation of the current account. On the other side of the spectrum are Hong Kong SAR and Singapore, where distortions amount to up to several percentage points of GDP, leading to an undervaluation of their current account. This is in contrast to the inflation distortion for these two countries, as we discuss

\footnotetext{
${ }^{23}$ e.g. Luxembourg and Ireland.
} 


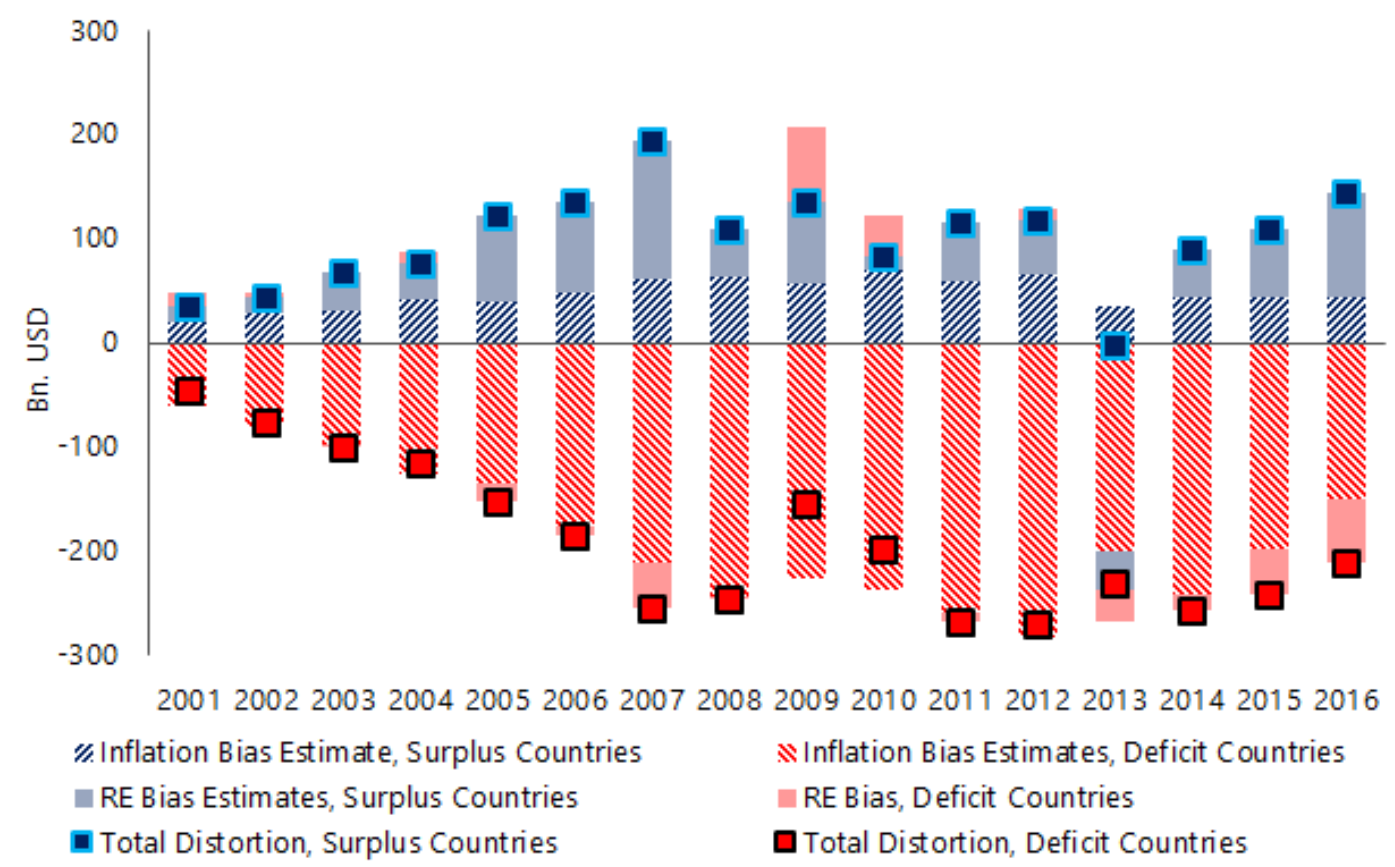

Figure 2: Estimated Global Retained Earnings and Inflation Distortions Average 2001-16. Sources: Thomson Reuters, Wealth of Nations Database, Currency Weights Database from Benetrix, Lane and Shambaugh (2015), Country Authorities, IMF's IFS Database, IMF's WEO Database, IMF's BOP Database, IMF's CPIS Database and Fund Staff Calculations.

next.

Figure 4 shows that the estimates for the inflation distortion are particularly large in a small group of financial center economies, most notably Hong Kong SAR, Singapore, followed by Switzerland and Belgium (Figure 4). Consistently in these countries, the inflation distortions lead to overestimation of the current account.

Figure 5 shows the two distortions stacked across the sample countries. In Hong Kong SAR and Singapore, where the distortions are large in absolute value, they partly cancel each other out, thereby narrowing the total distortion of the statistical measure of the current account. The inflation distortion dominates, however, placing these countries among those with the largest implied upwardly biased current accounts. Overall, the results point to consistently large total distortions primarily in economies considered financial centers, with large foreign investment positions. This conclusion also emerges from Figure 6, depicting the absolute distortion of the sample countries across different years against these countries' gross foreign assets in percent of GDP. Hong Kong SAR, Singapore, Switzerland and, to a lesser extent, Belgium and the UK, stand out.

It is important to emphasize that there is a large amount of uncertainty surrounding these point estimates. They do, however, suggest that measurement distortions may be 


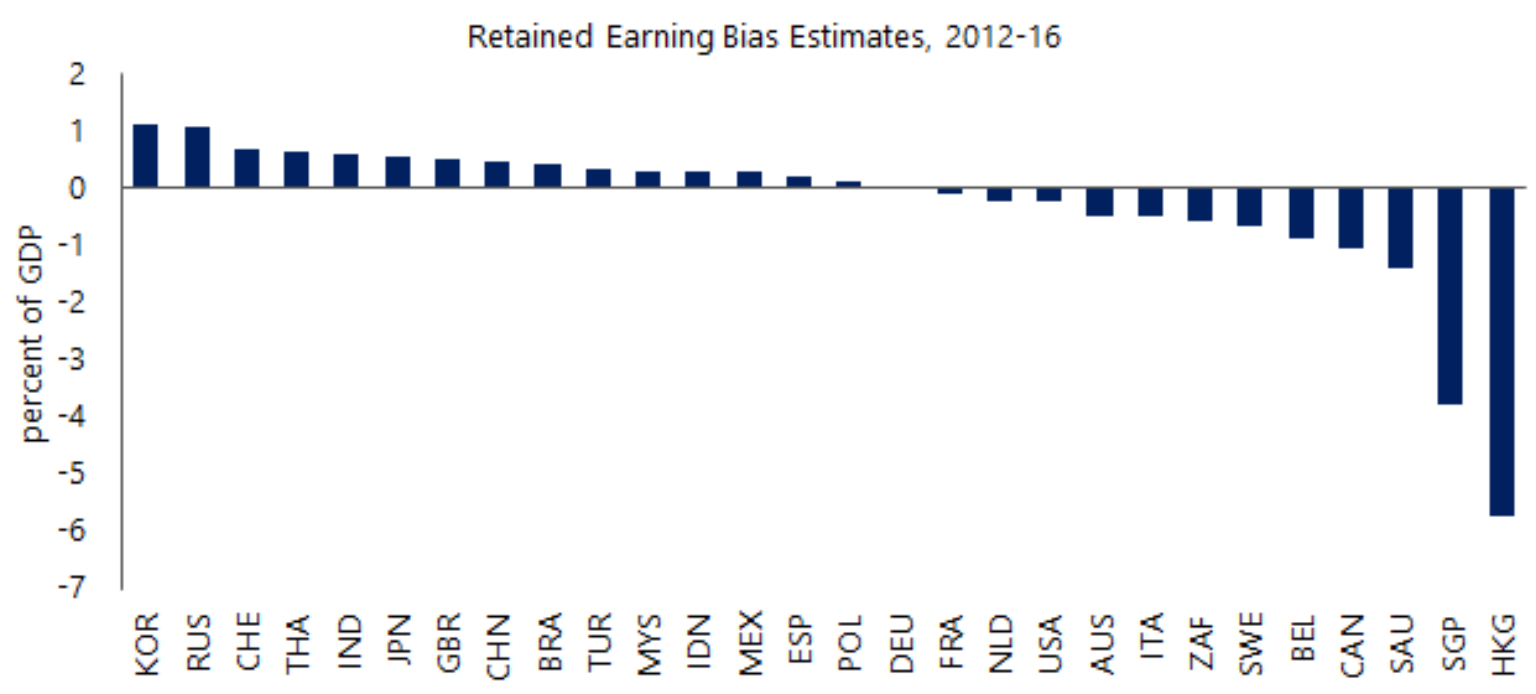

Figure 3: Estimates of the Retained Earnings Distortion

Average 2012-16. Averages of stock, flow and hybrid estimates of retained earnings distortion distortions by country from 2012-2016. Positive values means that the unadjusted current account overestimates the economic concept of the current account. Sources: Thomson Reuters, Wealth of Nations Database, IMF's IFS Database, IMF's WEO Database, IMF's BOP Database, IMF's CPIS Database and Fund staff calculations.

Inflation Bias Estimates, 2012-16

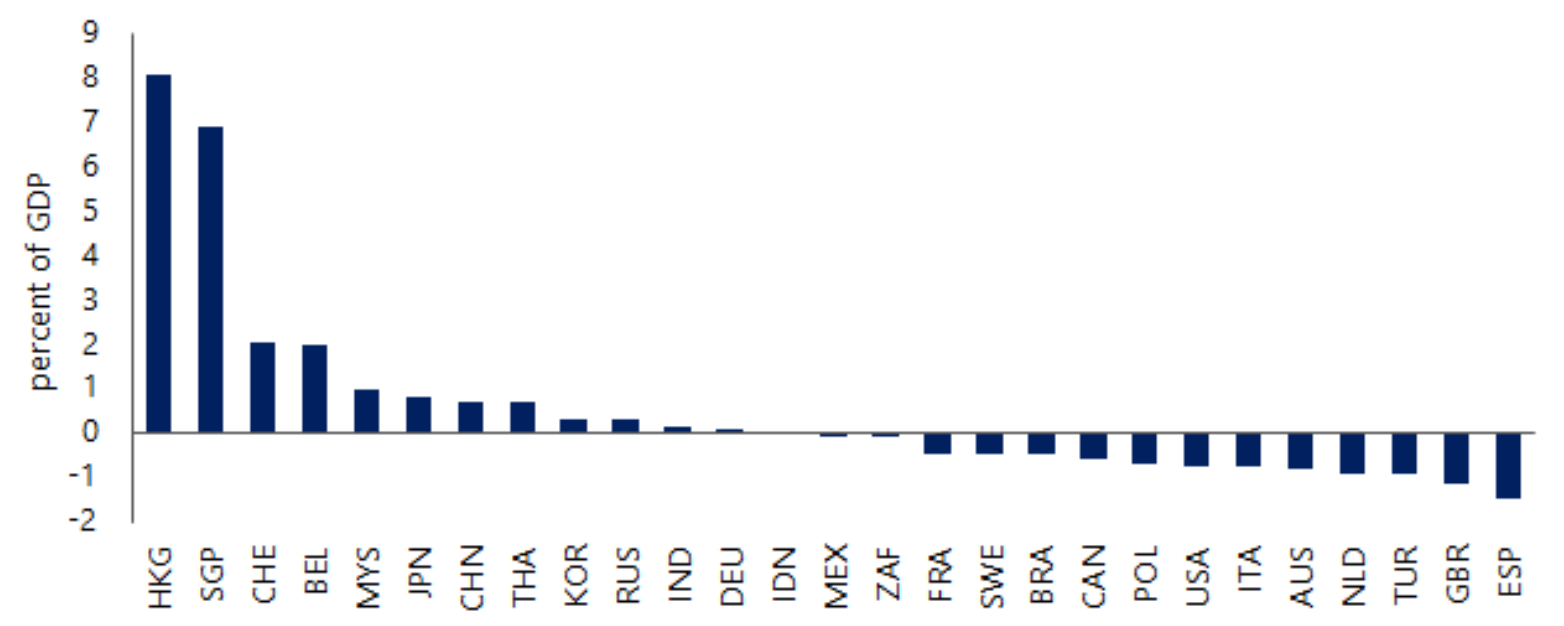

Figure 4: Estimates of the Inflation Distortion

Average 2012-16. Average inflation distortions by country from 2012-2016. 5 year moving averages of actual inflation are used as proxy for inflation expectations. Positive values means that the unadjusted current account overestimates the economic concept of the current account. Sources: Wealth of Nations Database, Currency Weights Database from Benetrix, Lane and Shambaugh (2015), Country Authorities, IMF's IFS Database, IMF's WEO Database, IMF's BOP Database, IMF's CPIS Database and Fund staff calculations. 


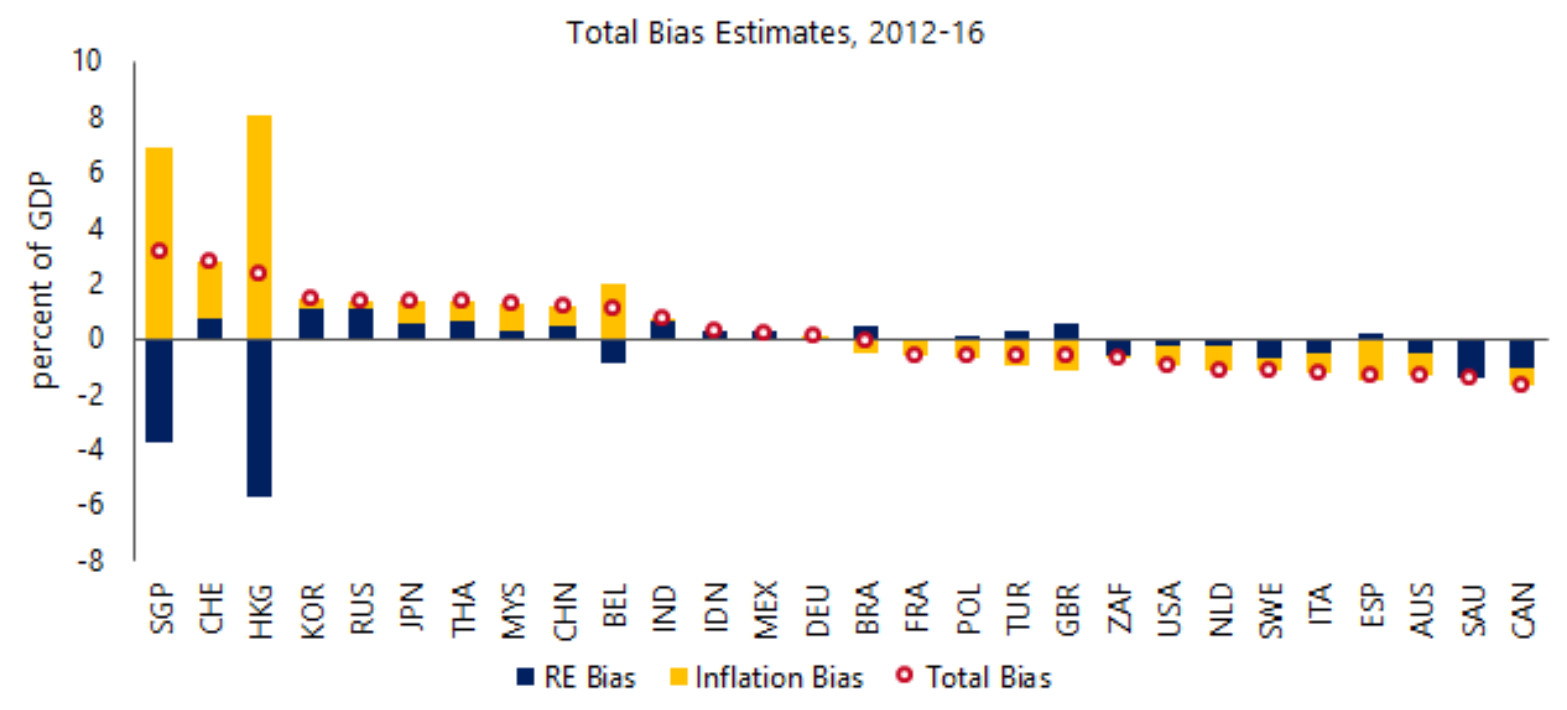

Figure 5: Inflation and Retained Earnings Distortions, 2012-16

Average distortions by country from 2012-2016. Positive values means that the unadjusted current account overestimates the economic concept of the current account. Sources: Fund staff calculations based on Thomson Reuters, External Wealth of Nations Database, IMF's IFS, WEO, BOP and CPIS Databases, Currency Weights from Bénétrix et al. (2015), Country Authorities.

able to partly explain developments in global imbalances, and particularly within economies with large gross foreign investment positions. Moreover, only two measurement distortions that can be meaningfully estimates for a large set of countries have been accounted for. Other sources of distortions could also be influential. The estimates are thus mostly indicative. $^{24}$ We have made a number of simplifying assumptions in order to produce estimates across a wide set of countries, taking into account data that are available consistently across countries. Refined country specific estimates could take advantage of the more detailed data occasionally available at the country level, notably on currency composition of foreign investment positions.

\section{Merchanting and Profit-shifting}

Recent studies have called attention to an empirical correlation between cross border merchanting activities (i.e., trade in goods between third-party countries with profits accruing to the domestic company) and overall current account balances, especially in economies with large external balances (Beusch et al. (2015), Fard et al. (2017)). Increasing integra-

\footnotetext{
${ }^{24}$ The IMF's normative framework for assessing external imbalances allows for country-specific adjustment in light of these distortions. Some level of mismeasurement beyond the two distortions is captured by the inclusion of net foreign assets as a regressor in current account models. See Cubeddu et al. (2019).
} 


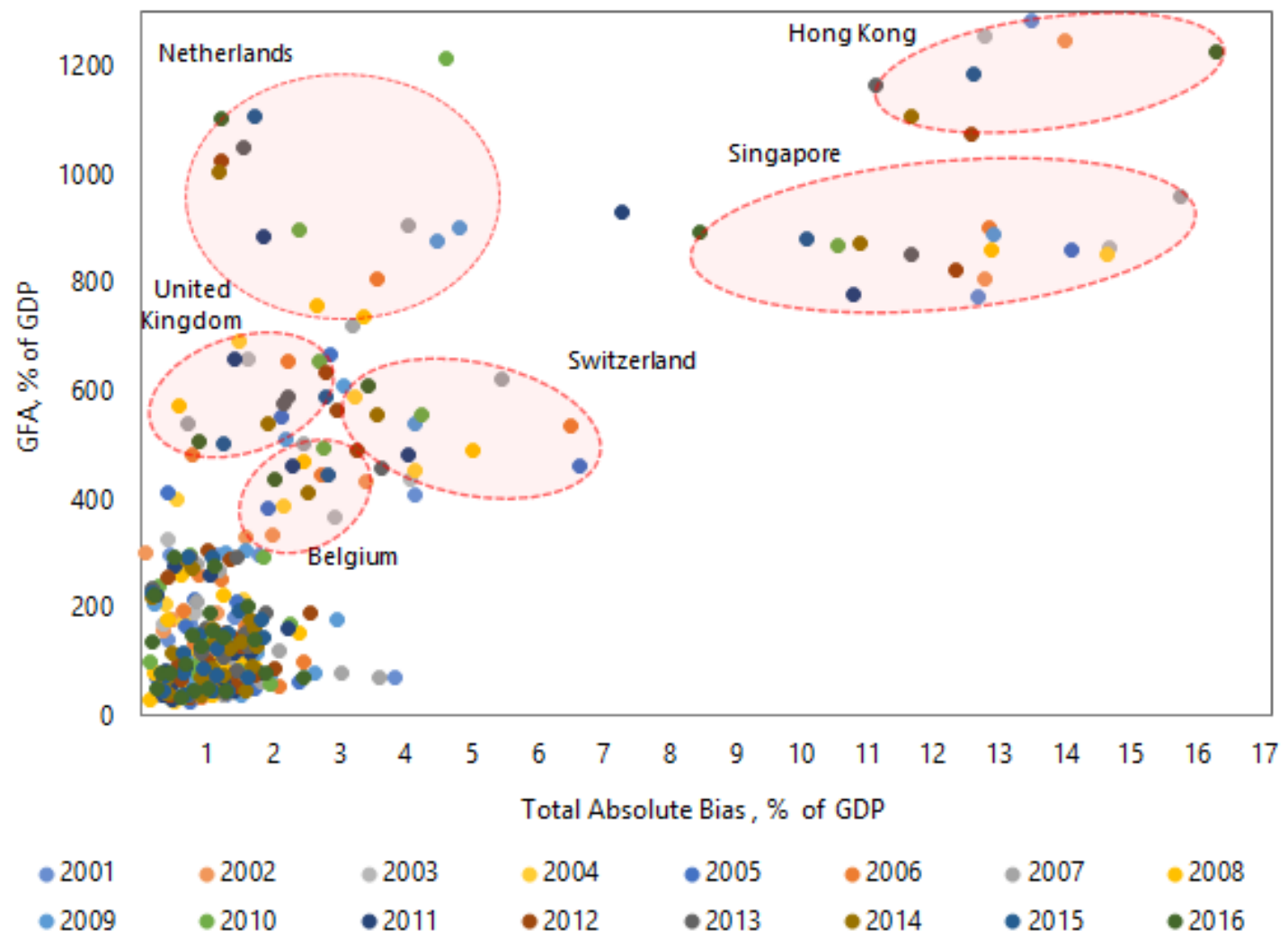

Figure 6: Gross Foreign Assets and Absolute Measurement Distortions

Absolute Measurement Distortions are the sum of the absolute value of the inflation and the retained earnings distortions. Each point represents a county-year. Gross foreign assets are in percent of GDP. Sources: Thomson Reuters, Wealth of Nations Database, Currency Weights Database from Benetrix, Lane and Shambaugh (2015), Country Authorities, IMF's IFS Database, IMF's WEO Database, IMF's BOP Database, IMF'c CPIS Database and Fund staff calculations. 
tion of production into global value chains also seems to be associated with an increase in merchanting activities as well as increasingly complex tax structures of multinational corporations (see also Bertaut et al. (2019)). While merchanting can affect how current account flows are divided between the income and the trade balance, our framework and analysis suggest that it is not conceptually clear how merchanting per se would distort the current account measure.

In the statistics, merchanting can take two forms, with different implications for external account statistics:

- True merchanting conducted by a domestically-owned company. True merchanting, or simply merchanting, should be thought of exports of the intermediation services associated with the buying and selling. Provided countries properly compile and report such activities, the presence of true merchanting activities should not affect the measurement of the current account. Merchanting activities should contribute positively to the current account balance, with a corresponding entry in the financial account (net accumulation of foreign assets), and there would be no reason to exclude these as measurement distortions. If true merchanting activities are carries out by foreign owned firms, it should not affect the currency account, as explained below.

- Profit shifting. International companies may set up subsidiaries in low tax rate jurisdictions for tax minimization purposes. Through transfer pricing practices, profits can then be shifted to those subsidiaries. The associated intra-company imports and exports are recorded as merchanting under the statistics of the country where the subsidiary is located. Thus, they contribute positively to the trade balance of the low tax jurisdiction. However, because the low-tax subsidiary is ultimately owned by the foreign company, the net merchanting balance is offset by a corresponding entry in the income balance, reflecting the payment of dividends (or the attribution of retained earnings) to the parent company. Except for the tax component, these profit-shifting activities should affect the composition of the current account, in terms of the breakdown between trade and income balances, but not the overall current account balance (see also Lane (2017)).

While profit shifting by multinationals can take place in many other complex and obscure forms, with broader effects (Lipsey (2010), Fatih Guvenen and Ruhl (2017), Lane $(2017))^{25}$, it is beyond the scope of this paper to exhaustively cover them. A clear conceptual argument to the effect that profit shifting distorts the measurement of the current account is lacking, however. Moreover, merchanting activities may simply be important in multinational firms that correlate with the types of measurement distortions we have explored above. The retained earnings distortion is a relevant candidate. A deeper, more

\footnotetext{
${ }^{25}$ Box 1.2 in IMF (2017) discusses the case of Ireland.
} 
granular, understanding of the effect of merchanting and profit shifting in multinational companies is needed to asses whether there are associated distortions in the measurement of external accounts. There is also a need to strengthen data collection efforts on cross border transactions and cross-border collaboration of statistical authorities on such efforts.

\section{Conclusions}

In this paper, we propose a unified conceptual framework for understanding the role of different measurement distortions in the income balance of the current account. The framework allows us to show that the statistical treatment of inflation, retained earnings, default risk and other aspects of investment income in current account statistics can have material implications for the measurement of external accounts. The framework is flexible and can be adapted to incorporate new distortions that may arise as global integration proceeds.

Based on estimates of the retained earnings and inflation distortions, we find that measurement distortions can be empirically non-negligible drivers of observed current account imbalances. These distortions tend to be more important in economies with large gross and net external investment positions.

While conceptual, practical and data limitations may prevent the adoption of a different statistical measures, it is central for good policy analysis that measurement distortions are taken into account in comprehensive assessments of countries' of external imbalances. The framework and specific estimates of distortiones presented in this paper represent a small step toward quantifying potential distortions. Data limitations remain an important constraint on more precise estimation of specific distortions, as well as taking into account new possible distortions such as that related to default risk. In the specific cases of the inflation and retained earnings distortions, the limited information on stock-flow reconciliation in external accounts, i.e. the statistics to reconcile flow information from balance of payments statistics with stock information from the international investment position, as well as limited information about the currency composition of the gross positions, are particularly constraining.

As integration in global value chains proceeds, a better conceptual understanding of how multinational corporations shift profits cross borders between subsidiaries, and how this affects external accounting, will also be needed. 


\section{References}

Adler, Gustavo, and Daniel Garcia-Macia. 2018. "The Stabilizing Role of Net Foreign Asset Returns." working paper no.18/79, International Monetary Fund.

Bénétrix, Agustin S., Philip R. Lane, and Jay C. Shambaugh. 2015. "International currency exposures, valuation effects and the global financial crisis." Journal of International Economics, 96(S1): 98-109.

Bertaut, Carol, Beau Bressler, and Stephanie E Curcuru. 2019. "Globalization and the geography of capital flows." In Are post-crisis statistical initiatives completed?. ed. by Bank for International Settlements, 49 of IFC Bulletins chapters: Bank for International Settlements.

Beusch, Elisabeth, Barbara Döbeli, Andreas Fischer, and Pinar Yeşin. 2015. "Marchanting and the Current Account." The World Economy 140-167.

Cubeddu, Luis M., Signe Krogstrup, Gustavo Adler, Pau Rabanal, Mai Chi Dao, Swarnali Ahmed Hannan, Luciana Juvenal, Carolina Osorio Buitron, Cyril Rebillard, Daniel Garcia-Macia, and Callum Jones. 2019. "The External Balance Assessment Methodology: 2018 Update." IMF Working Papers 19/65, International Monetary Fund.

Dooley, Michael P., David Folkerts-Landau, and Peter Garber. 2004. "The revived Bretton Woods system." International Journal of Finance \& Economics, 9(4): 307-313.

Fard, Liv Hakimi, Sofia Kaahre, and Maria Sandstroem. 2017. "Merchanting and multinational enterprises - important explanations for Sweden's current account surplus." staff memo, Sveriges Riksbank.

Fatih Guvenen, Dylan G. Rassier, Raymond J. Mataloni, and Kim J. Ruhl. 2017. "Offshore Profit Shifting And Domestic Productivity Measurement." Working Paper Series 23324 .

Fischer, Andreas M., Henrike Groeger, Philip Sauré, and Pinar Yeşin. 2019. "Current account adjustment and retained earnings." Journal of International Money and Finance, 94(C): 246-259.

Fletcher, Kevin. 2019. "How Much Does Inflation Distort Current Account Balances?." Forthcoming IMF Working Paper, International Monetary Fund. 
Gourinchas, Pierre-Olivier, and Hélène Rey. 2007. "From world banker to world venture capitalist: US external adjustment and the exorbitant privilege." In Gr Current Account Imbalances: Sustainability and Adjustment.: University of Chicago Press, 11-66.

Hausmann, Ricardo, and Federico Sturzenegger. 2007. "The missing dark matter in the wealth of nations and its implications for global imbalances." Economic Policy, 22 469-518.

Hill, Robert J., and T. Peter Hill. 2003. "Expectations, Capital Gains, and Income." Economic Inquiry, 41(4): 607-619.

IMF. 2009. "Balance of Payments and International Investment Positions Manual." manual, International Monetary Fund.

IMF. 2017. "World Economic Outlook."Technical report, International Monetary Fund.

Jump, Gregory V. 1980. "Interest Rates, Inflation Expectations, and Spurious Elements in Measured Real Income and Saving." The American Economic Review, 70(5): 9901004 .

Kramp, Paul Lassenius, Anne Ulstrup Mortensen, and Casper Winther Nguyen Jørgensen. 2018. "Globalization Complicates Current Account Interpretation." Analysis, Danmarks Nationalbank(2): .

Lane, Philip R. 2015. "A Financial Perspective on the UK Current Account Deficit." National Institute Economic Review, 234(1): 67-72.

Lane, Philip R. 2017. "The Treatment of Global Firms in National Accounts." Economic Letter Series, Central Bank of Ireland, 2017(1): .

Lane, Philip R., and Gian Maria Milesi-Ferretti. 2007. "A Global Perspective on External Positions." In G7 Current Account Imbalances: Sustainability and Adjustment.: National Bureau of Economic Research, Inc, 67-102.

Lee, Jaewoo, Jonathan David Ostry, Alessandro Prati, Luca A Ricci, and Gian M Milesi-Ferretti. 2008. "Exchange Rate Assessments; CGER Methodologies." IMF Occasional Papers 261, International Monetary Fund.

Lipsey, Robert E. 2010. "Measuring The Location Of Production In A World Of Intangible Productive Assets, Fdi, And Intrafirm Trade." Review of Income and Wealth, 56(s1): 99-110. 
Mancini, Tommaso, and Nicolas Stoffels. 2012. "Adjusting the Current Account to Better Capture Wealth Accumulation." mimeo, Swiss National Bank.

Mian, Olga, and Philipp Saure. 2017. "Cross-Country Inflation Differentials as a Source of Switzerland's Current Account Surplus." manuscript, International Monetary Fund.

Milesi-Ferretti, Gian Maria, and Philip R. Lane. 2017. "International Financial Integration in the Aftermath of the Global Financial Crisis." Working Paper 115, International Monetary Fund.

Obstfeld, Maurice. 1986. "Capital mobility in the world economy: Theory and measurement." Carnegie-Rochester Conference Series on Public Policy, 24(1): 55-103.

Obstfeld, Maurice. 2012. "Does the Current Account Still Matter?." American Economic Review, 102(3): 1-23.

Reinsdorf, Dominique Durant Kyle Hood, Marshall, and Leonard Nakamura. 2017. "Improving The Treatment Of Holding Gains And Default Losses In National Accounts." Review of Income and Wealth, 63.

Vanoli, Andre. 1999. "Interest and Inflation Accounting." Review of Income and Wealth, 45(3): 279-302. 


\section{A Data}

Table 1: Data Sources

\begin{tabular}{|c|c|c|}
\hline Variable & Source & Notes \\
\hline \multirow[t]{3}{*}{$\begin{array}{l}\text { Currency Weights of In- } \\
\text { ternational Debt Posi- } \\
\text { tions }\end{array}$} & $\begin{array}{l}\text { Bénétrix, Agustin S. and Lane, Philip R. } \\
\text { and Shambaugh, Jay C., 2015. Inter- } \\
\text { national Currency Exposures, Valuation } \\
\text { Effects and the Global Financial Crisis } \\
\text { Database }\end{array}$ & $\begin{array}{l}\text { Shares of US Dollar, Euro, GB Pound, } \\
\text { Japanese Yen, Swiss Franc and domestic } \\
\text { currency in total international investment } \\
\text { in debt instruments. }\end{array}$ \\
\hline & $\begin{array}{l}2018 \text { IMF survey on stock-flow reconcilia- } \\
\text { tion and currency composition of interna- } \\
\text { tional investment position. }\end{array}$ & $\begin{array}{l}\text { Data available for Switzerland, Belgium, } \\
\text { Russia, Germany, Poland, France, Italy, } \\
\text { Turkey, Spain, China and Brazil. }\end{array}$ \\
\hline & IMF Balance of Payments Database & $\begin{array}{l}\text { Used for currency composition of foreign } \\
\text { debt in Japan. }\end{array}$ \\
\hline $\begin{array}{l}\text { Debt Instruments, } \\
\text { Portfolio Investment }\end{array}$ & $\begin{array}{l}\text { Philip R. Lane and Gian Maria Milesi- } \\
\text { Ferretti, The External Wealth of Nations } \\
\text { Database }\end{array}$ & $\begin{array}{l}\text { Foreign Portfolio Investment Positions in } \\
\text { Debt Instruments, in USD }\end{array}$ \\
\hline $\begin{array}{l}\text { Debt Instruments, Di- } \\
\text { rect Investment }\end{array}$ & IMF International Financial Statistics & $\begin{array}{l}\text { Foreign Direct Investment Positions in } \\
\text { Debt Instruments, in USD }\end{array}$ \\
\hline Reserve Assets & $\begin{array}{l}\text { Philip R. Lane and Gian Maria Milesi- } \\
\text { Ferretti, The External Wealth of Nations } \\
\text { Database }\end{array}$ & Total Reserve Assets, in USD \\
\hline Inflation & IMF World Economic Outlook Database & $\begin{array}{l}\text { Percentage change in Consumer Prices, } \\
\text { period average }\end{array}$ \\
\hline $\begin{array}{l}\text { Investment } r \text { Income } \\
\text { on Portfolio As- } \\
\text { sets/Liabilities }\end{array}$ & IMF Balance of Payments Database & $\begin{array}{l}\text { Investment income on equity and invest- } \\
\text { ment fund shares, credit/debit balances in } \\
\text { USD }\end{array}$ \\
\hline Dividend-Yield Ratio & Thomson Reuters Datastream & \\
\hline Price-Earnings Ratio & Thomson Reuters Datastream & \\
\hline $\begin{array}{l}\text { Portfolio Equity As- } \\
\text { sets/Liabilities }\end{array}$ & IMF Balance of Payments Database & $\begin{array}{l}\text { Equity and Investment Fund Shares, in } \\
\text { USD }\end{array}$ \\
\hline $\begin{array}{l}\text { Portfolio Equity As- } \\
\text { sets/Liabilities, bilat- } \\
\text { eral country exposure } \\
\text { weights }\end{array}$ & $\begin{array}{l}\text { IMF Coordinated Portfolio Investment } \\
\text { Survey }\end{array}$ & $\begin{array}{l}\text { Share of each counter-part country in each } \\
\text { country's total portfolio assets/liabilities. }\end{array}$ \\
\hline $\begin{array}{l}\text { Current Account Bal- } \\
\text { ance }\end{array}$ & IMF World Economic Outlook Database & In USD \\
\hline Nominal GDP & IMF World Economic Outlook Database & In USD \\
\hline
\end{tabular}

